\title{
Profil społeczny i analiza wybranych czynników ryzyka chorób sercowo-naczyniowych u pacjentów zakwalifikowanych do operacji pomostowania aortalno-wieńcowego
}

\author{
Analysis of selected risk factors for cardiovascular diseases in patients scheduled for \\ Coronary Artery Bypass Graft
}

\author{
Aleksandra Szylińska, 2, Anna Mikołajczyk, 2, Mateusz Pytlak, Hanna Mosiejczuk', Mariusz Listewnik², \\ Magdalena Ptak', Iwona Rotter ${ }^{1}$
}

1 Samodzielna Pracownia Rehabilitacji Medycznej Pomorskiego Uniwersytetu Medycznego w Szczecinie

ul. Żołnierska $54,71-210$ Szczecin

Kierownik: dr n. med. Iwona Rotter

2 Klinika Kardiochirurgii Pomorskiego Uniwersytetu Medycznego w Szczecinie

al. Powstańców Wlkp. 72, 70-111 Szczecin

Kierownik: prof. dr hab. n. med. Mirosław Brykczyńsk

\section{SUMMARY}

Introduction: Cardiovascular diseases are classified as diseases of civilization, and constitute a major social problem because they are the main cause of death. For this reason, according to the WHO, more than 17.3 million people die every year in developed countries. In the European Union the number of deaths is over 2 million, and represents $42 \%$ of total mortality.

The aim of the study was analysis of selected risk factors for cardiovascular disease in patients scheduled for surgical revascularization, and an outline of their social profile.

Material and methods: The study was conducted among patients scheduled for surgery in Cardiac Surgery Department SPSK no. 2 in Szczecin. Ninety patients were studied. The research was carried out using proprietary diagnostic surveys and data obtained from medical records.
Results: The selected modifiable risk factors for diseases of the cardiovascular system were evaluated. In the study group 15 patients (17\%) were current smokers. Most patients (38, 42\%) had not smoked for more than 2 years. 33 patients (37\%) suffered from diabetes. More than half $(47,52 \%)$ of the respondents did not follow a balanced diet. Most of the patients were obese (37, 41\%), including 18 diabetics and 19 non-diabetics. 58 patients (64\%) suffered from hypertension.

Conclusion: Diabetes, obesity, and smoking were confirmed as risk factors for coronary heart disease. The educational activity of family doctors should be mainly focused on the prevention of diabetes, stopping smoking, and lifestyle changes in order to prevent diseases of the cardiovascular system, especially among the elderly.

Key words: BMI, diabetes, risk factors.

\section{STRESZCZENIE}

Wstęp: Choroby sercowo-naczyniowe są zaliczane do chorób cywilizacyjnych i stanowią duży problem społeczny, ponieważ są główną przyczyną zgonów. Według danych Światowej Organizacji Zdrowia (World Health Organization - WHO), co roku z powodu chorób układu krążenia w krajach wysoko rozwiniętych umiera ponad 17,3 mln osób. W Unii Europejskiej liczba zgonów wynosi ponad $2 \mathrm{mln}$ i stanowi $42 \%$ ogólnej umieralności. Celem pracy była analiza wybranych czynników ryzyka chorób sercowo-naczyniowych u pacjentów zakwalifikowanych do chirurgicznej rewaskularyzacji serca oraz zarys ich profilu społecznego.

Materiał i metody: Badania zostały przeprowadzone wśród pacjentów zakwalifikowanych do operacji w Klinice Kardiochirurgii Samodzielnego Publicznego Szpitala Klinicznego nr 2 Pomorskiego Uniwersytetu Medycznego w Szczecinie (SPSK-2 PUM). Wzięło w nich udział 90 pacjentów. Badania zostały przeprowadzone metodą sondażu diagnostycznego z wykorzystaniem autorskiej ankiety oraz danych uzyskanych z dokumentacji medycznej.

Wyniki: Ocenie poddano wybrane modyfikowalne czynniki ryzyka chorób układu sercowo-naczyniowego. W badanej grupie aktualnie palących było 15 (17\%) osób. Najwięcej, 38 (42\%) pacjentów nie paliło papierosów dłużej niż 2 lata. Na cukrzycę choruje 33 (37\%) pacjentów. Ponad połowa - 47 (52\%) badanych wskazała, że odżywia się nieracjonalnie. Większość pacjentów była otyła 37 (41\%), w tym chorujących na cukrzycę - 18 i niechorujących - 19. Na nadciśnienie chorowało 58 (64\%) pacjentów. Wniosek: Potwierdzonymi w badaniach czynnikami predysponującymi do choroby wieńcowej były: cukrzyca, otyłość oraz palenie papierosów. Prewencja cukrzycy, zaprzestanie palenia tytoniu, zmiana stylu życia powinny być głównymi działaniami edukacyjnymi w praktyce lekarza rodzinnego w celu zapobiegania chorobom układu sercowo-naczyniowego, zwłaszcza wśród osób starszych.

Słowa kluczowe: BMI, cukrzyca, czynniki ryzyka. 


\section{WSTĘP}

Według Światowej Organizacji Zdrowia (World Health Organization - WHO) choroba wieńcowa należy do chorób cywilizacyjnych i jest dużym problemem społecznym w Polsce oraz na świecie. Główną przyczyną zgonów w krajach rozwiniętych są choroby układu sercowo-naczyniowego. Według danych WHO, z ich powodu co roku w krajach wysoko rozwiniętych umiera ponad 17,3 mln osób [1, 2, 3]. W Unii Europejskiej liczba zgonów z tego powodu przekracza $2 \mathrm{mln}$ i stanowi $42 \%$ w ogólnej umieralności [4]. W Polsce w 2010 r. choroby układu sercowo-naczyniowego były przyczyną 46\% zgonów (40,8\% wśród mężczyzn i 51,8\% u kobiet). Wśród chorób układu krążenia najczęstszą przyczyną śmierci jest choroba wieńcowa 45,8 tys. (26\%) zgonów, w tym z powodu zawału mięśnia sercowego 17,8 tys. (10\%) ogółu przyczyn sercowo-naczyniowych [5]. Według wyników badań opublikowanych w 2003 r. w Polsce umieralność z powodu chorób układu sercowo-naczyniowego w przedziale wiekowym 25-64 lat była 2,5-krotnie wyższa niż w innych krajach Unii Europejskiej. Główną przyczyną było zwiększone występowanie czynników ryzyka chorób układu sercowo-naczyniowego w populacji polskiej [6]. Obecnie opisanych jest ponad 300 modyfikowalnych i niemodyfikowalnych czynników ryzyka, które zaburzają czynność lub uszkadzają śródbłonek i głębsze warstwy ścian naczyń krwionośnych [4]. Zapobieganie występowaniu modyfikowalnych czynników ryzyka chorób układu sercowo-naczyniowego jest istotnym działaniem w zwalczaniu ich występowania.

Przeprowadzone w ostatnich latach liczne badania wykazały zależność pomiędzy wskaźnikiem masy ciała (body mass index BMI) a występowaniem chorób sercowo-naczyniowych. Otyłość u pacjentów powyżej 65. r.ż. jest powszechnym problemem i współprzyczyną wielu chorób oraz zaburzeń o podłożu metabolicznym: cukrzycy, hiperlipidemii czy nadciśnienia tętniczego. Wyższa wartość wskaźnika BMI zwiększa ryzyko wystąpienia choroby wieńcowej [7]. Według wyników badań, głównie otyłość brzuszna ma negatywny wpływ na układ sercowo-naczyniowy, ponieważ tłuszcz odkłada się nie tylko w tkance podskórnej, ale również w narządach wewnętrznych $[7,8,9,10]$. Otyłości towarzyszy przewlekły stan zapalny oraz oporność tkanek na insulinę, co sprzyja migracji i osadzaniu się makrofagów w ścianie naczyń krwionośnych oraz przyspiesza proces rozwoju niestabilnej blaszki miażdżycowej [7, 11, 12]. Otyłość nazywana epidemią obecnych czasów została zakwalifikowana przez WHO do chorób przewlekłych. Problem otyłości jest niebezpiecznym czynnikiem ryzyka, który zwiększa odsetek zachorowań na choroby układu krążenia oraz śmiertelność [13]. Z tego powodu głównym celem działań zapobiegających wystąpieniu choroby niedokrwiennej serca jest prewencja pierwotna. W polskim systemie zdrowia pacjent najpierw trafia do lekarza rodzinnego, a dopiero później jest kierowany do lekarza kardiologa lub diabetologa. Dlatego tak ważna jest prowadzona przez lekarza rodzinnego edukacja pacjenta oraz kontrola masy ciała, poziomu cholesterolu i cukru we krwi. Edukacja pacjenta na temat prawidłowych zasad odżywiania oraz aktywności fizycznej powinna być prowadzona u wszystkich pacjentów, a w szczególności u pacjentów z co najmniej jednym czynnikiem ryzyka wystąpienia choroby układu krążenia.

Celem pracy była analiza wybranych czynników ryzyka chorób sercowo-naczyniowych u pacjentów zakwalifikowanych do chirurgicznej rewaskularyzacji serca oraz zarys ich profilu społecznego.

\section{MATERIAt I METODY}

Badania przeprowadzono u pacjentów z chorobą wieńcową zakwalifikowanych do zabiegu pomostowania tętnic wieńcowych w Klinice Kardiochirurgii Samodzielnego Publicznego Szpitala Klinicznego nr 2 Pomorskiego Uniwersytetu Medycznego w Szczecinie (SPSK-2 PUM) w okresie od stycznia do kwietnia 2015 r. W badaniach wzięło udział 90 pacjentów, w tym 68 (76\%) mężczyzn oraz 22 (24\%) kobiety. Średnia wieku badanych pacjentów wynosiła $65 \pm 7$ lat. Badania przeprowadzone zostały metodą sondażu diagnostycznego z wykorzystaniem autorskiej ankiety oraz danych uzyskanych z dokumentacji medycznej. Ankiety były wypełniane zgodnie z wymaganiami etycznymi, samodzielnie przez pacjentów na sali chorych. Od każdego pacjenta, oprócz zgody na przeprowadzenie badania, uzyskano podstawowe dane dotyczące wieku, wykształcenia, pracy zawodowej, sposobu odżywiania, aktywności fizycznej, palenia tytoniu. Pytania dotyczyły także chorób współistniejących: cukrzycy, nadciśnienia tętniczego oraz chorób nerek. Dodatkowo z historii choroby zostały zebrane dane na temat: masy ciała, wzrostu, ciśnienia tętniczego, częstotliwości rytmu serca oraz poziomu hemoglobiny glikolizowanej $\left(\mathrm{HbA}_{1} \mathrm{c}\right)$.

Klasyfikację wartości ciśnienia tętniczego przeprowadzono zgodnie z wytycznymi Polskiego Towarzystwa Nadciśnienie Tętniczego [14].

Oprócz klasyfikacji nadciśnienia tętniczego w badanej grupie na podstawie wzrostu i ciężaru ciała wyliczono wartości BMI wg wytycznych WHO.

Średnie stężenie glukozy we krwi badane w okresie 3 miesięcy od oznaczenia określane jest za pomocą $\mathrm{HbA}_{1} \mathrm{c}$. Badanie wykonywane jest u każdego pacjenta przyjętego do zabiegu kardiochirurgicznego. Jest to jeden ze wskaźników, który pozwala na rozpoznanie cukrzycy, gdy $\mathrm{HbA}_{1 \mathrm{c}}$ jest równe lub wyższe niż 6,5\%.

Analizę statystyczną przeprowadzono z użyciem elementów statystki opisowej przy użyciu licencjonowanego programu Statistica 10 (StatSoft, Inc. Tulsa, OK, USA). Do statystycznej oceny rozkładu badanej zmiennej wykorzystano test W Shapiro-Wilka oraz testy: $\chi^{2}$ i U Manna-Whitneya. Wyniki zostały przedstawione w postaci procentowej oraz średniej arytmetycznej i odchylenia standardowego. Istotność statystyczna została określona przy wartości $\mathrm{p}<0,05$.

\section{WYNIKI}

\section{Profil społeczny}

Wśród przebadanych pacjentów najwięcej, bo 39 (44\%), mieszkało w miastach od 10 tys. do 100 tys. mieszkańców, w miastach 
powyżej 100 tys. mieszkało 22 (25\%), na wsi mieszkało 16 (18\%), a najmniej, bo 13 (14\%), zamieszkiwało w miastach do 10 tys. W badanej grupie $22(25 \%)$ osoby miały wykształcenie podstawowe, 29 (32\%) zawodowe, 28 (31\%) średnie, a 11 (12\%) pacjentów miało wykształcenie wyższe. Większość ankietowanych pacjentów była w związkach małżeńskich - 74 (82\%) osoby. Liczba osób niepracujących wynosiła 66 (73\%), pracę z przewagą wysiłku umysłowego zadeklarowało 13 (15\%), a z przewagą wysiłku fizycznego 11 (12\%) osób.

\section{Czynniki ryzyka \\ 1. Otyłość}

Średnia wartość BMI w badanej grupie wyniosła 28,9. Większość ocenianych pacjentów była otyła - 37 (41\%) osób, 33 (37\%) miało nadwagę, a normalną wagę ciała miało 20 (22\%) pacjentów. Różnice z podziałem na płeć były istotne statystycznie $(\mathrm{p}<0,00)$. Wyniki przedstawiono $\mathrm{w}$ tabeli 1.

TABELA 1. Kategoria BMI w zależności od ptci

\begin{tabular}{lcccc} 
Kategoria & Mężczyźni & Kobiety & Razem & p \\
\hline \multirow{2}{*}{ Norma } & 13 & 7 & 20 & NS \\
& $19 \%$ & $32 \%$ & $22 \%$ & \\
\hline \multirow{2}{*}{ Nadwaga } & 30 & 3 & 33 & $<0,01$ \\
\hline \multirow{2}{*}{ Otyłość } & $44 \%$ & $14 \%$ & $37 \%$ & NS \\
& 25 & 12 & 37 & \\
\hline \multirow{2}{*}{ Razem } & $37 \%$ & $54 \%$ & $41 \%$ & $<0,05$ \\
& 68 & 22 & 90 & \\
\hline
\end{tabular}

NS - nieistotny statystycznie

\section{Palenie papierosów}

Aktualnie paliło 15 (17\%) pacjentów. Najwięcej, bo 58 (64\%) pacjentów paliło papierosy w przeszłości, w tym 38 (42\%) do ponad 2 lat, 8 ( $9 \%$ ) do pół roku, a 12 (13\%) do jednego miesiąca przed operacją. Nigdy nie paliło papierosów 17 (19\%) pacjentów. Analiza rozkładu według płci wykazała istotne statystycznie różnice $(\mathrm{p}<0,015)$. Wyniki przedstawiono $\mathrm{w}$ tabeli 2. Natomiast nie było statystycznie uchwytnych związków pomiędzy paleniem tytoniu a miejscem zamieszkania $(p>0,6)$ i wykształceniem $(\mathrm{p}>0,9)$.

TABELA 2. Palenie tytoniu w zależności od płci pacjentów

\begin{tabular}{lcccc} 
Kategoria & Mężczyźni & Kobiety & Razem & p \\
\hline Niepalący & 13 & 4 & 17 & NS \\
\hline Palący & $19 \%$ & $18 \%$ & $19 \%$ & \\
w przeszłości & $71 \%$ & 10 & 58 & $<0,05$ \\
\hline Palący & 7 & $86 \%$ & $64 \%$ & NS \\
aktualnie & $10 \%$ & $36 \%$ & $17 \%$ & \\
\hline Razem & 68 & 22 & 90 & $<0,05$ \\
\hline
\end{tabular}

NS - nieistotny statystycznie

\section{Cukrzyca}

Kolejnym czynnikiem ryzyka wystąpienia chorób układu krążenia jest cukrzyca. W badanej grupie na cukrzycę choruje 33 (37\%) pacjentów, w tym 23 (34\%) mężczyzn i 10 (45\%) kobiet. $\mathrm{W}$ badanej grupie wszyscy pacjenci chorujący na cukrzycę mieli wartości $\mathrm{HbA}_{1}$ c powyżej 6,5 mg\%. Jednocześnie, u żadnego pacjenta bez cukrzycy w rozpoznaniu nie stwierdzono podwyższonego poziomu $\mathrm{HbA}_{1} \mathrm{c}$.

\section{Styl życia}

Ankietowanych pacjentów pytano o subiektywną ocenę sposobu odżywiania się. Ponad połowa badanych zaznaczyła, że odżywia się niezgodnie z zasadami racjonalnego żywienia - 47 (52\%), w tym z cukrzycą 17 (52\%), a bez cukrzycy 30 (53\%). Trzech pacjentów (9\%) z cukrzycą oceniło swój sposób odżywiania się jako właściwy, 9 (27\%) za być może odpowiedni, a 4 (12\%) za wyjątkowo niewłaściwy. Żaden z badanych pacjentów nie odpowiedział, że odżywia się całkowicie zgodnie z zaleceniami lekarskimi.

W pytaniu o liczbę posiłków spożywanych w ciągu dnia pacjenci częściej zaznaczali odpowiedź powyżej 3 - 46 (51\%), w tym z cukrzycą 24 (73\%), a bez cukrzycy 22 (39\%). Spożywanie 2 posiłków dziennie zadeklarowało 40 (44\%), w tym z cukrzycą 7 (21\%), a bez cukrzycy aż 33 (57\%) pacjentów. Tylko 4 (4\%) pacjentów zaznaczyło 1 posiłek dziennie.

Przeanalizowano również zależności pomiędzy występowaniem cukrzycy a BMI pacjentów. Większość z nich była otyła 37 (41\%), w tym chorujących na cukrzycę 18 (55\%) i pozostałych - 19 (33\%). Kolejną grupą byli pacjenci z nadwagą, bez cukrzycy - 22 (39\%), a z cukrzycą 11 (33\%) osób. Prawidłowe BMI miało 4 (12\%) pacjentów z cukrzycą i 16 (28\%) bez cukrzycy. Wykazano istotne statystycznie różnice pomiędzy występowaniem cukrzycy a BMI $(\mathrm{p}<0,049)$.

W łącznej ocenie całej grupy różnice nie były istotne statystycznie, natomiast wśród chorych z otyłością różnice przekroczyły granice istotności statystycznej przy poziomie $\mathrm{p}<0,05$.

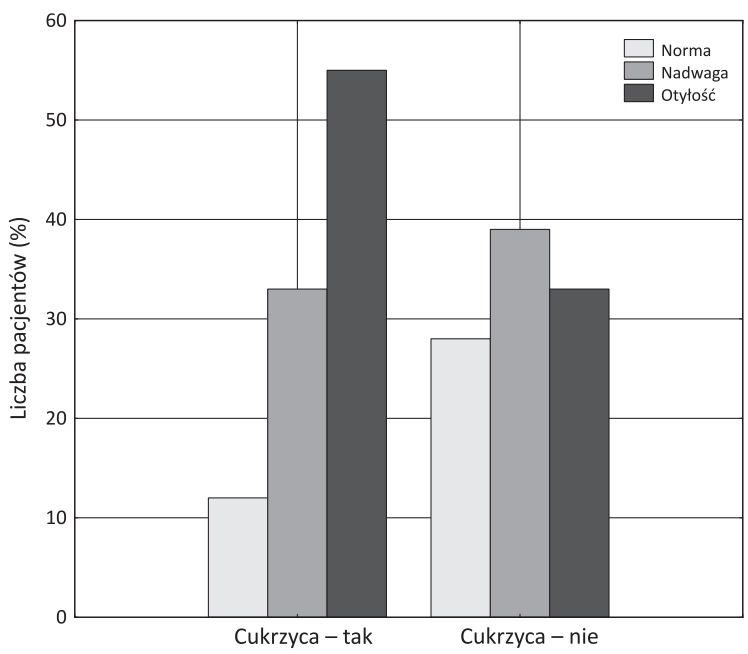

RYCINA 1. Cukrzyca a wskaźnik masy ciała

Najwięcej pacjentów z grupy badanej - 32 (36\%), w tym 25 mężczyzn i 7 kobiet preferowało spontaniczną aktywność fizyczną, 31 (34\%) pacjentów (26 mężczyzn i 5 kobiet) przejawiało zaplanowaną aktywność ruchową częściej niż raz w tygodniu, a 8 (9\%) osób tylko raz w tygodniu. Brak aktywności fizycznej w ankietach zaznaczyło 19 (21\%) osób, w tym 12 mężczyzn i 7 kobiet. Większość pacjentów z otyłością preferuje 
aktywność fizyczną częściej niż raz w tygodniu (14), a brak aktywności - 6. Większość pacjentów z nadwagą wybrało w ankiecie aktywność fizyczną spontaniczną - 11. Ze względu na małe liczebności w podgrupach, dla celu obliczeń statystycznych połączono kategorie aktywności raz w tygodniu i więcej niż raz w tygodniu, jednak nie wykazano istotnych statystycznie różnic pomiędzy aktywnością fizyczną pacjentów a klasą BMI $(\mathrm{p}>0,9)$.

\section{Nadciśnienie tętnicze}

Kolejnym ocenianym czynnikiem ryzyka chorób układu sercowo-naczyniowego było nadciśnienie tętnicze. W badanej grupie na nadciśnienie choruje 58 (64\%) pacjentów, w tym 39 mężczyzn i 19 kobiet. Najwięcej pacjentów chorujących na nadciśnienie było w grupie wiekowej powyżej 60. r.ż. - 52. Wśród cukrzyków chorujący na nadciśnienie stanowili 90\% badanych (30 na 33). Wśród 9 pacjentów, którzy podali w ankiecie chorobę nerek, 7 chorowało dodatkowo na nadciśnienie, a 4 na cukrzycę i nadciśnienie. Wśród chorujących na nadciśnienie najwięcej było pacjentów z otyłością - 28 (76\%), z nadwagą - 21 (63\%) i z BMI w zakresie normy - 9 (45\%).

Jeżeli zostaną przyjęte podstawowe kryteria czynników ryzyka, wśród ocenianych można wyróżnić cztery istotnie zwiększające ryzyko wystąpienia choroby wieńcowej: nadciśnienie tętnicze, cukrzycę, otyłość i palenie tytoniu. W ocenianej grupie wystąpienie 4 czynników ryzyka stwierdzono u $11(12 \%)$ pacjentów, 3 u 69 (77\%), a 2 - u 10 (11\%).

\section{DYSKUSJA}

W ciągu ostatniego ćwierćwiecza Polska bardzo zbliżyła się do krajów wysoko rozwiniętych. Dotyczy to również wydłużenia się średniej długości życia i spadku liczby urodzeń, co zaowocowało przyspieszonym starzeniem się społeczeństwa. Informacje na temat czynników ryzyka chorób sercowo-naczyniowych funkcjonują oczywiście w przestrzeni publicznej, ale są słabo adresowane do konkretnych grup ryzyka. Za mało mówi się o konieczności okresowych badań Polaków w wieku powyżej 40. r.ż., co umożliwiłoby powszechniejsze wprowadzenie prewencji pierwotnej chorób sercowo-naczyniowych.

Otyłość jest jednym z modyfikowalnych czynników ryzyka chorób sercowo-naczyniowych. W badaniach częstości ich występowania Główczyńska i wsp. w ramach programu POLKARD-SPOK wykazali występowanie otyłości u 30,2\%, a nadwagi u 46,4\% [15]. Sulicka i wsp. zaobserwowali nadwage u 46,7\%, a otyłość u 24,6\% badanych [6]. Pojawiają się artykuły na temat paradoksu otyłości, czyli dłuższego życia osób z nadwagą i otyłością niż szczupłych chorujących na chorobę wieńcową, niewydolność serca i nadciśnienie. Jednak według większości wyników badań otyłość jest stanem szkodliwym, natomiast co do nadwagi zdania są podzielone. Takie różnice mogą wynikać z ułomności samego BMI, który nie podaje stopnia otłuszczenia organizmu oraz typu otyłości, a także nie ma odniesienia do wieku. Dodatkowym czynnikiem predysponującym do większej umieralności osób z prawidłową wagą mogą być inne czynniki nieujęte w badaniach, np. palenie tytoniu [16]. W badaniach przeprowadzonych w Klinice Kardiochirurgii SPSK-2 PUM większość pacjentów z chorobą wieńcową zakwalifikowanych do zabiegu pomostowania aortalno-wieńcowego miała BMI wskazujące na otyłość (41\%) i nadwagę (37\%). Wśród pacjentów chorujących na chorobę wieńcową aktualnie palących papierosy było $17 \%$ badanych, a niepalących 19\%. Według wyników badań Sulickiej i wsp. papierosy paliło $28,5 \%$ badanych [6].

Badanie wpływu nadciśnienia tętniczego nie wykazało istotności statystycznej w korelacji z BMI, co wynikać może z dużej częstości występowania nadciśnienia w tej grupie pacjentów. Nadciśnienie w badanej grupie zaobserwowano u 64,4\% pacjentów - o 10\% mniej niż w badaniach Sulickiej i wsp. (74\%) [6]. Zbliżone wyniki uzyskano $w$ badaniach prowadzonych w ramach programu POLKARD (59,3\%), natomiast o połowę niższe wartości uzyskano w ramach badania NATPOL PLUS [15, 17].

Kolejnym modyfikowalnym czynnikiem ryzyka chorób sercowo-naczyniowych jest cukrzyca. Oczywiście, podobnie jak w przypadku nadciśnienia chodzi tu o modyfikowalność w sensie postawienia rozpoznania i prawidłowo prowadzonego leczenia. Według wyników badań własnych na cukrzycę choruje $37 \%$ ocenianych pacjentów. W badaniu POLKARD częstość występowania cukrzycy wyniosła $28,5 \%$, podczas gdy u Sulickiej i wsp. 19\%, a w badaniu NATPOL PLUS zaledwie $5,6 \%$ [6, 17]. Tak duże różnice mogą wynikać z kilku przyczyn. Bardzo istotny może być czas przeprowadzenia badania, gdyż w ostatnich latach wraz ze starzeniem się społeczeństwa częstość występowania cukrzycy rośnie niezwykle szybko. W Klinice Kardiochirurgii SPSK-2 PUM średni wiek pacjentów operowanych z powodu choroby wieńcowej wzrósł z 56 lat w $1990 \mathrm{r}$. do ponad 64 w 2013 r. Podobnie z częstością występowania cukrzycy - z 9\% w 1990 r. do blisko 40\% w 2013 r. Niski odsetek pacjentów z cukrzycą w badaniu NATPOL PLUS pochodzi stąd, że wyniki dotyczą całej populacji, a nie specyficznej grupy, jaką są pacjenci kwalifikowaniu do operacji pomostowania tętnic wieńcowych. Badana grupa pacjentów zakwalifikowanych do chirurgicznej rewaskularyzacji serca ten etap ma już za sobą, ale przez właściwą edukację prozdrowotną prowadzoną w ramach prewencji wtórnej można wpłynąć na poprawę odległych wyników leczenia chirurgicznego. Okres pobytu w szpitalu może być wykorzystany do podnoszenia świadomości pacjentów na temat wagi ich zachowań w okresie pooperacyjnym - właściwego trybu życia, odżywiania się, samokontroli poziomu glikemii i wartości ciśnienia tętniczego. Efekty nowoczesnego leczenia chirurgicznego naczyń wieńcowych nie zostaną w pełni wykorzystane, jeśli nie będzie prowadzona prewencja wtórna, edukacja pacjentów w zakresie monitorowania i modyfikacji czynników ryzyka choroby sercowo-naczyniowej.

\section{WNIOSKI}

Wpływ modyfikowalnych czynników ryzyka takich jak otyłość, nikotynizm, dieta, aktywność fizyczna oraz prawidłowo prowadzonego leczenia nadciśnienia tętniczego i cukrzycy 
na wystąpienie choroby wieńcowej, a także jej ewentualny nawrót po leczeniu operacyjnym powinny zostać ujęte w edukacji pacjentów prowadzonej podczas pobytu w szpitalu. Potwierdzonymi w badaniach czynnikami predysponującymi do choroby wieńcowej są: cukrzyca, otyłość i palenie papierosów. Prewencja cukrzycy, zaprzestanie palenie ty toniu, zmiana stylu życia powinny być głównym działaniem edukacyjnym w praktyce lekarza rodzinnego w celu zapobiegania chorobom układu sercowo-naczyniowego, zwłaszcza wśród osób starszych. Promocja zdrowego stylu życia, prewencja pierwotna i w tórna oraz zwiększenie świadomości społeczeństwa na temat modyfikacji czynników ryzyka chorób układu krążenia powinny być głównym działaniem personelu medycznego w przychodniach i szpitalach.

\section{PIŚMIENNICTWO}

1. Szymańska L.A., Małkowska B., Ładny J.Ł.: Zawał mięśnia sercowego, niestabilna choroba wieńcowa, tętniak aorty piersiowej i zator tętnicy płucnej jako najczęstsze przyczyny hospitalizacji pacjentów z bólem w klatce piersiowej. Przegl Kardiodiabetol. 2012, 7 (2), 78-84.

2. Kobus G., Tomaszuk-Kazberuk A., Bachórzewska-Gajewska H., Kuleszyńska A., Małyszko J., Dobrzycki S. et al.: Nadciśnienie tętnicze i cukrzyca u pacjentów ze stabilną chorobą wieńcową kierowanych na koronarografię. Przegl Kardiodiabetol. 2012, 7 (1), 8-14.

3. Wróblewska I., Adamowicz E., Sochocka L., Steciwko A.: Rola prewencji w chorobie wieńcowej serca. Badania własne w oddziale kardiologii interwencyjnej w Zgorzelcu. Fam Med Prim Care Rev. 2011, 13 (2), 257-263.

4. Logstrup S., O'Kelly S.: European Cardiovascular Disease Statistics. European Heart Network, Brussels 2012, 35-44.
5. Wojtyniak B., Goryński P., Moskalewicz B.: Sytuacja zdrowotna ludności Polski i jej uwarunkowania. Narodowy Instytut Zdrowia Publicznego Państwowy Zakład Higieny, Warszawa 2012.

6. Sulicka J., Fornal M., Gryglewska B., Wizner B., Grodzicki T.: Wybrane czynniki ryzyka chorób sercowo-naczyniowych u pacjentów podstawowej opieki zdrowotnej. Nadciś Tętn. 2006, 10 (5), 370-376.

7. Bogołowska-Stieblich A., Tałałaj M.: Otyłość a choroby układu sercowo-naczyniowego. Post N Med. 2013, 5b, 19-25.

8. Li C., Engstrom G., Hedbald B.: Sex differences in the relationships between BMI, WHR and incidence of cardiovascular disease: a population-based cohort study. Int J Obes (Lond). 2006, 30 (12), 1775-1781.

9. Freiberg M.S., Encina M.J., D'Agostino R.B., Lanier K., Wilson P.W., Vasan R.S.: BMI vs. waist circumference for identifying vascular risk. Obesity. 2008, 16 (2), 463-469.

10. Yusuf S., Hawken S., Ounpuu S., Bautista L., Franzosi M.G., Commenrford P. et al.: Obesity and the risk of myocardial infarction in 27000 participants from 52 countries: a case-control study. Lancet. 2005, 366, 1640-1649.

11. Ridker P.M., Cushman M., Stampfer M.J., Tracy R.P., Hennekens C.H.: Inflammation, aspirin, and the risk of cardiovascular disease in apparently healthy men. N Engl J Med. 1997, 336 (14), 973-979.

12. Abel E.D., O'Shea M., Ramasamy R.: Insulin resistance: metabolic mechanism and consequences in the heart. Arterioscler Thromb Vasc Biol. 2012, 32 (9), 2068-2076.

13. Zasady postępowania w nadciśnieniu tętniczym. Stanowisko Polskiego Towarzystwa Nadciśnienia Tętniczego 2003. Nadciśn Tętn. 2003, 7 (Suppl. A), A3-A21.

14. Wójtowicz-Chomicz K., Borzęcki A.: Czy wśród studentów Uniwersytetu Medycznego w Lublinie występuje zjawisko otyłości. Fam Med Prim Care Rev. 2011, 13 (2), 251-253.

15. Główczyńska R., Pietrasika A., Starczewska M.E., Filipiak K., Opolski G.: Czynniki ryzyka zdarzeń sercowo-naczyniowych w populacji pacjentów podstawowej opieki zdrowotnej. Przew Lek. 2005, 6, 52-57.

16. Cybulska B., Kłosiewicz-Latoszek L.: Co znaczy paradoks otyłości w chorobie wieńcowej? Kardio Pol. 2013, 71 (9), 963-968.

17. Zdrojewski T., Bandosz P., Szpakowski P.: Rozpowszechnienie głównych czynników ryzyka chorób układu sercowo-naczyniowego w Polsce. Wyniki badania NATPOL PLUS. Kardiol Pol. 2004, 61, 5-26. 